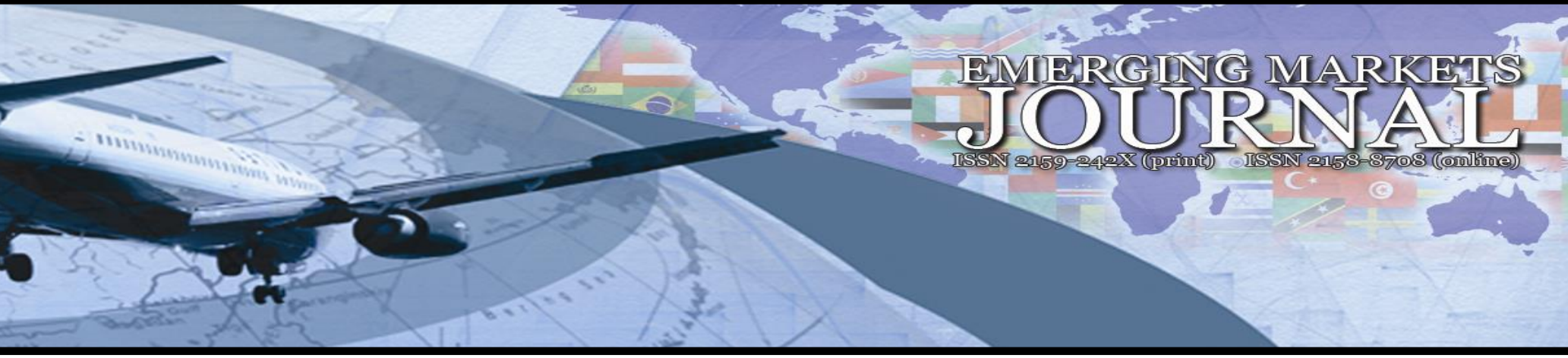

\title{
Factors affecting Attitudes towards Adoption of Mobile Banking: Users and Non-Users Perspectives
}

Cherinet Boke Chakiso

Ankara Yildirim Beyazit University, Turkey | chrnt.b@gmail.com

Volume 9 No 1 (2019) ｜ ISSN 2158-8708 (online) | DOI 10.5195/emaj.2019.167 | http://emaj.pitt.edu |

\begin{abstract}
The advent and dispersal of technology is an interesting area of study since its success is dependent on the attitude for the adoption of it by customers. Extant literature indicates that mobile banking is the least adopted type of electronic banking when compared to other types of banking like Automated Teller Machine (ATM), despite its being the cheapest and quickest mode of communication. This study empirically examines and tests factors affecting users and non-users' attitude towards the adoption of mobile banking. Data were collected from 256 participants both from users and non-users of mobile banking. Collected data were analyzed using chi-square, ANOVA, and correlation analysis. Findings indicate that trust, perceived ease of use, relative advantage, and compatibility have strong correlations with both users and non-users' adoption towards mobile banking. However, perceived risk is found to have no significant relationship with users and nonusers' attitude towards the adoption of mobile banking. Moreover, it is found that there is a difference between users and non-users' attitude towards the adoption of mobile banking. Furthermore, managerial implications, limitations of the study and future research directions were discussed.
\end{abstract}

Keywords: Trust, Perceived Ease of Use, Perceived Risk, Relative Advantage, Compatibility, Attitude

* The author would like to thank Professor Omur Akdemir for his constructive comments on the earlier drafts of this study.

\section{(cc) Br}

New articles in this journal are licensed under a Creative Commons Attribution 3.0 United States License.

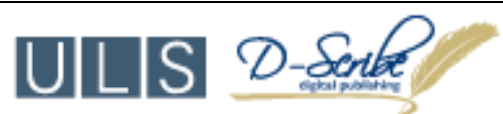

This journal is published by the University Library System of the University of Pittsburgh as part

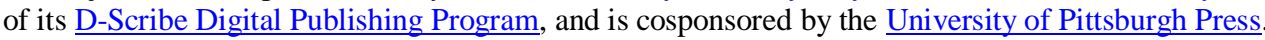




\section{Factors affecting Attitudes towards Adoption of Mobile Banking: Users and Non-Users Perspectives}

\section{Cherinet Boke Chakiso}

\section{Introduction}

Technology is becoming one of the bases for competitions in all facets of human activities (Sohail and Al-Jabri, 2014). It was during the 1970s that automated teller machines (ATM) followed by mobile banking in the 1980s which were introduced to banking distribution channels (Mullen, Bradley and Loane, 2017). Among those technologies, mobile banking and service transactions play a vital role in the day to day life of marketers and customers (Laukkanen, 2017). Mobile banking as one of the promising technologies for modern society (Baabdullah, Alalwan, Rana, Kizgin, and Patil, 2019), empirical evidence indicates that the adoption of mobile banking improves the quality of human life and furthers the efficiency of banks (Malaquias and Hwang, 2016). As one of the quickest and cheapest modes of communication, mobile phones are now providing not only hello but also made banking services to palms of customers.

Chawla and Joshi (2017) defined mobile banking as "using a mobile phone for performing financial transactions such as getting account information, transferring funds, request for a checkbook, opening or renewing fixed deposits, opening a dematerialized account, opening a loan account, making utility payments, and so on". Laukkanen \& Pasanen, (2008) defined mobile banking as "a channel whereby the customer interacts with a bank via a mobile device such as a smartphone or a personal digital assistant".

Mobile banking provides several banking services with full of efficiency for both bankers and customers. This unequivocally promotes service efficiency for both customers as well as bankers (Sohail and Al-Jabri, 2014). Similarly, Szopiński (2016) pointed out that the use of electronic banking can reduce costs for both customers and bankers. Studies about mobile banking and its antecedents have got significant attention from academics since its inception to technology market (Kim, Shin, and Lee 2009; Khasawneh, 2015; KoenigLewis, Palmer, and Moll, 2010). Findings of Wan and Chow (2005) indicate that mobile banking is the least adopted type of electronic banking when compared to other types of banking like ATM.

Davies et al. (1989) proposed the user's acceptance model for new technology. Technology Adoption Model (TAM) is one of the most widely used and discussed a model for predicting the adoption of users for new technology and innovation (Chawla and Joshi, 2017). In cases where customers have alternative ways of getting service, the rate of adoption for new technology would be no easy task. As new technological innovations at infancy stage usually face barriers to technological adoption, mobile banking is no exception (Luo, Li, Zhang, and Shim, 2010). The existing literature about the adoption of mobile banking technology adoption is more centered on developed countries (Sohail and Al-Jabri, 2014). Calhoun et al. (2002) underlined the difference in culture for technology adoption. In the case of Turkish context, Akturan and Tezcan (2012) conducted the adoption of mobile banking in the context of youth market but they collected data from only nonusers and suggested other studies to focus on users. Tam and Oliveira (2016) pointed out that there is a lack of studies which focus on post-adoption of mobile banking. Moreover, there are no comparative studies in Turkey that empirically investigated both users and nonusers attitude towards mobile banking. Therefore, the purpose of this study is to investigate the factors affecting both users and nonusers attitude towards the adoption of mobile banking in Turkey.

\section{Conceptual Framework}

This section reviews the literature and attempts to synthesize extant studies based on the previous theory that can explain factors which can affect the attitudes of customers towards the adoption of mobile banking.

\section{Trust}

Trust is among the vital factors in exchange relationship between two partners to have noble outcomes such as loyalty (Morgan and Hunt, 1994; Chakiso, 2015) and related with satisfaction (Luakkannen, 2017). The existing uncertainty with mobile banking and service by its nature make one of the critical factors for marketers (Luo, Li, Zhang, and Shim, 2010). Trust is the partners' confidence in exchange for partners reliability and integrity (Morgan and Hunt, 1994). As cited by Singh and Srivastava (2018), in mobile banking, trust is defined as "the belief that allows individuals to willingly become vulnerable to the bank, the telecommunication provider, and the mobile technology after having the banks, and the telecommunication provider's characteristic embedded in the technology artefact" Masrek et al. (2012). Morgan and Hunt (1994) asserted that in rational contracting behavior, trust plays a vital role between exchange partners. The trust between the exchange partners leads to productivity and efficiency preceded by cooperative behavior (Morgan and Hunt, 1994). Building trust would take time and it differs types of offerings especially in services which are intangible in nature (Chakiso, 2015). For example, Chawla and Joshi (2017) pointed out that the level of trust varies for different types of technological innovations associated with its perceived risks. Chawla and Joshi's (2017) finding indicates that trust predicted $68 \%$ of users perceived adoption of mobile banking. Correspondingly, the findings of Koenig-Lewis (2010) indicate that trust and credibility found to be crucial in reducing the overall perceived risk of mobile banking. Chawla and Joshi's (2017) finding indicate that trust is one of the most important elements in banking transactions, especially in online banking. 
Trust can be developed between exchange partners with three integral parts namely successful accomplishment and provision of service, ethically delivering service with full integrity with no deceiving, and caring the needs of customers by due benevolence (Farah, Hasni, and Abbas, 2019). Despite its developmental stages, some studies indicate that initial trust is the most important (Gao and Waechter, 2015) and it can build at the early stages of exchange relations with the exchange partners (Sharma and Sharma, 2019). In an empirical study, Farah et al. (2018) found that trust predicts mobile banking adoption intention.

H1a: Trust has a positive and significant effect on users attitude towards the adoption of mobile banking.

H1b: Trust has a positive and significant effect on nonusers attitude towards the adoption of mobile banking.

Perceived Ease of Use

Perceived ease of usefulness (PEU) can be defined as the degree to which an innovation is easy to use (Lin, 2010). Davis (1989) defined PEU as achieving innovation with free of effort and perceiving that mobile banking is advantageous and make service easier (Akturan, 2012). Akturan (2012) studied about mobile banking adoptions and found that perceived ease of use has a positive and significant effect on customers. In the study of user's adoption of internet banking, Yiu, Grant, and Edgar (2007) found that perceived ease of use has a direct relationship with the user's adoption to internet banking. In contrary, Boateng, Adam, Okoe, And Dorson (2016) found that perceived ease of use has no significant effect on user's adoption of internet banking. This would be due to the difference in culture for the adoption of new innovative technology.

H2a: Perceived ease of use has a positive and significant effect on users attitude towards the adoption of mobile banking.

H2b: Perceived ease of use has a positive and significant effect on nonusers attitude towards the adoption of mobile banking.

\section{Perceived Risk}

Perceived risks are factors that make consumer contemplate about the nature and amount of risk for purchase decision (Bauer, 1960). Murray (1991) conceptualized that due to inseparability nature of service, perceived risk is higher in service than goods. Moreover, Consumers lack knowledge about the product increases consumers perceived risk. Murray (1991) stated that the greater perceived risk increases the consumer's propensity to seek information about the product. This depends on the consumer's source of information (for example, friends, family, media, etc.) acceptance and readiness for the service for purchase decision and continual use.
Studies on technology adoption indicate that perceived risk is one of the important factors that affect consumers attitudes and intention towards the adoption of new technology. For example, Laforet and Li, (2005) found that perceived risk is one of the important factors for the adoption decision of Chinese customers.

There are major dimensions of risks which are identified by Jacoby and Kaplan, (1972); Kaplan, Jacoby, and Szybillo, (1974) and, time risk is by Roselius (1971) and more recently by (Featherman and Pavlou, 2003). They are shown below in table 1 .

\section{Table 1: Types of Risks}

\begin{tabular}{|l|l|}
\hline Financial risk & $\begin{array}{l}\text { The potential monetary cost incurred to make the } \\
\text { product work properly, or to replace it with a } \\
\text { satisfactory product (Roselius, 1971: 58). }\end{array}$ \\
\hline $\begin{array}{l}\text { Product } \\
\text { risk }\end{array}$ & $\begin{array}{l}\text { The loss incurred when a brand or product does not } \\
\text { perform as expected (Forsythe and Shi, 2003: 869). }\end{array}$ \\
\hline Social risk & $\begin{array}{l}\text { "Potential loss of status in one's social group as a } \\
\text { result of adopting a product or } \\
\text { service, looking foolish or untrendy" (Featherman and } \\
\text { Pavlou, 2003: 455). }\end{array}$ \\
\hline Physical risk & $\begin{array}{l}\text { The potential risk of that can be sustained by using the } \\
\text { product. }\end{array}$ \\
\hline Psychological \\
risk & $\begin{array}{l}\text { The risk of potential disappointment, frustration, and } \\
\text { shame experienced if one's personal information is } \\
\text { disclosed (Forsythe and Shi, 2003: 869). }\end{array}$ \\
\hline Time risk & $\begin{array}{l}\text { refer to the loss of time and inconvenience incurred } \\
\text { due to difficulty of navigation and/ or submitting } \\
\text { order, finding appropriate Web sites, or delays } \\
\text { receiving products (Forsythe and Shi, 2003: 869). }\end{array}$ \\
\hline Privacy risk & $\begin{array}{l}\text { "Potential loss of control over personal information, } \\
\text { such as when information about you is used without } \\
\text { your knowledge or permission." (Featherman and } \\
\text { Pavlou, 2003: 455) }\end{array}$ \\
\hline Overall Risk & $\begin{array}{l}\text { "A general measure of perceived risk when all criteria } \\
\text { are evaluated together." (Featherman and Pavlou, } \\
\text { 2003: 455) }\end{array}$ \\
\hline
\end{tabular}

Akturan (2012) found that, performance risk and social risk have a direct and significant effect on nonusers' attitude towards the adoption of mobile banking. Riquelme \& Rios (2010) found that, social risk can affect the intention to adopt mobile banking. Similarly, Farah et al. (2018) determined that, perceived risk predicts intention to adopt mobile banking. Therefore, it can be hypothesized as:

H3a: Perceived risk has a positive and significant effect on users' attitude towards the adoption of mobile banking.

H3b: Perceived risk has a positive and significant effect on non-user's attitude towards the adoption of mobile banking.

\section{Compatibility}

Compatibility can be defined as the extent to which innovation is compatible with the existing beliefs and values of the user previous experiences and habits (Chen and Tan, 2004; Sohail and Al-Jabr, 2014). Among those factors that shape individual's values and beliefs are social norms and those products that the extent to 
which products long depend on the fit with the trend of the society (Kotler and Keller, 2012: 311). In an empirical study, Riquelme and Rios (2010) found that social norms (including families, friends, etc.) have a direct influence on the adoption of mobile banking. Similarly, Sohail and Al-Jabr (2014) found that compatibility can impact the adoption of mobile banking. Besides, Kotler and Keller (2012: 153) stated that reference groups can influence individuals' attitude or behavior directly or indirectly. Chawla and Joshi (2017) corroborated that perceived lifestyle compatibility is one of the most important predictors of attitude and intention of mobile banking adoption. Lin (2011) asserted that the congruence in lifestyle as an important factor affecting user attraction towards technology-oriented services.

H4a: Compatibility has a positive and significant effect on users' attitude towards the adoption of mobile banking.

$\mathrm{H} 4 \mathrm{~b}$ : Compatibility has a positive and significant effect on non-users' attitude towards the adoption of mobile banking.

\section{Relative Advantage}

Williamson (2007) stated that human agents are intendedly rational even if their rationality is bounded. Thus, rational agents seek comparative benefits by comparing alternative services (here in this case as mobile banking instead of other distribution channels) and opportunity costs. In an empirical study, Shareef et al (2018) finding indicates that functional benefit found to be the strongest predictor of user adoption of mobile banking. Shareef et al. (2008) defined perceived functional benefit as "the degree to which consumers perceive the overall functional benefits, both absolute and relative-including cost, time, efficiency, and effectiveness of using mobile banking system-instead of using traditional physical office functions". It is explained in extant literature with different names like perceived benefit (Lin, 2011; Akturan and Tezcan, 2012); perceived efficiency (Chawla and Joshi, 2017); relative advantage (Sohail and Al-Jabr, 2014). All these concepts in their respective studies underlined about the economic benefit functions mobile bank fulfills, and relative efficiency mobile bank provides to the user in comparison to predecessors (see also Rogers, 2003).

H5a: Relative advantage has a positive and significant effect on users attitude towards mobile the adoption of banking.

H5b: Relative advantage has a positive and significant effect on users attitude towards mobile the adoption of banking.

Demographics

Extant literature indicates that there is a significant difference between groups of demographic characteristics (age, gender, education, income, occupation, so on) and attitude and intention towards the use of mobile banking (Chawla and Joshi, 2017). Laforet and $\mathrm{Li} \mathrm{(2005)} \mathrm{found} \mathrm{that} \mathrm{males,} \mathrm{young} \mathrm{age,} \mathrm{and} \mathrm{highly}$ educated are predominant users of mobile and online banking. Similarly, Kolodinsky, Hogarth, and Hilgert (2004) found that demographic variables of income, assets, age, marital status, education, and gender can affect adoption or intention in electronic banking technologies over time. Akinci, Aksoy, and Atilgan (2004) findings indicated that males, middle-aged adults, educated persons were users of internet banking. Again, Shareef et al. (2018) finding corroborated that middleaged, highly educated, males are predominant users of mobile banking and have more tendency to the adoption of new technology.

H6: There is a difference between across genders on the adoption of mobile banking.

Attitude

Fishbein and Azjein (1975) defined "Attitude" as an individual's positive or negative feelings about performing a target behavior. Davis (1989) pointed out that, the attitude of user has a relationship with IT usage. The behavioral orientation of the user is heavily dependent on the favorable attitude of the user towards the product. Rogers (2003) developed the diffusion of innovation theory and identified factors that can influence how the products are adopted by users. In one of the classic studies, Davis (2003) developed a technology adoption model which involves user adoption of innovation and behavioral intention.

Extant literature about the study of attitude towards a given product is analyzed for various types of products like computers, stores, internet banking, mobile banking, and so on. Most of these studies embraced perceived usefulness, compatibility, and ease of use to measure the attitude of user towards a given innovation (Taylor and Todd, 1995; Davis, 1989; Sohail and AlJabr, 2014; Chawla and Joshi; 2017). Moreover, a host of studies proposed and found that, attitude is antecedent of behavioral intention (Taylor and Todd, 1995; Davis, 1989; Sohail and Al-Jabr, 2014).

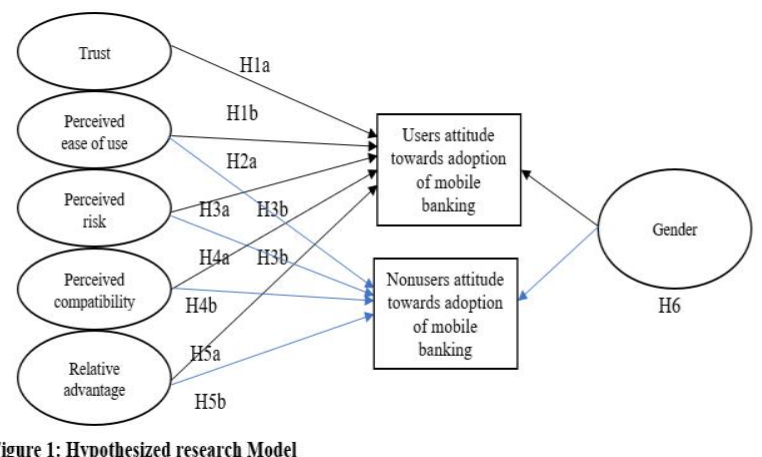

Figure 1: Hypothesized research Model

\section{Methods}

This study is conducted with the objective of assessing factors that can influence attitudes towards the adoption of mobile banking both from users and nonusers of it. Among quantitative approaches, this study 
followed correlational research design which is used for relating variables or predicting outcomes (Cresswell, 2012). This design suited to employ a cross-sectional self-administered survey was employed which is one of the cheapest and popular methods of data collection in quantitative designs in social science (Neuman, 2014). A number of studies have recommended survey in previous related studies (Sharma and Sharma, 2019; Saunders, Lewis and Thornhill, 2007).

The sample was drawn from university students in the city of Ankara, Turkey irrespective of their age, gender, level of education and other demographic factors. In total, 256 responses were collected from university students. The data for this study was collected through a survey questionnaire. A self-administered questionnaire was distributed for participants through online. Before the actual distribution of data, 20 samples were distributed to sample respondents for checking any problems with measurement. Then, some corrections were found, and the edited survey was effectuated.

For analyzing the data, descriptive statistics of frequencies and percentages were employed followed by discussions. Moreover, nonparametric tests of chi-square statistic are employed for demographic variables for the first part of the study. For the second part of the questionnaire survey, correlation analysis was employed for analyzing the relationship between theoretically identified influencing factors and users and nonusers' attitude towards mobile banking. Finally, the results were interpreted and discussion and analysis and compare the findings of this study with previous literature.

\section{Measures}

\section{Instrument}

The instrument employed in this study which is the survey questionnaire consists of two parts. First part is about questions which demographics of the respondents viz. gender, age, level of education, user nonuser status of mobile banking and the purpose of using mobile banking if they are users. The second part consists of the multi-item measures which are constructed to measure the concept of attitude with five constructs namely perceived trust, perceived risk, perceived usefulness, perceived compatibility, and perceived functional benefit.

The first part of the instrument consists of close-ended questions in the form of multiple questions. In the second part, each item consists of multi-items. Trust consists of 3 questions which are adapted from Koenig-Lewis, Palmer, and Moll (2010) perceived risk contains 3 items which are adapted from Sohail and AlJabr (2014). On the other hand, relative advantage consists of three questions and are adapted from Akturan and Tezcan (2012) with a little modification to make it align with the purpose of the study. And lastly, Perceived compatibility contains five items adapted from Sohail and Al-Jabr (2014) and relative advantage consists of 8 items adapted from Sohail and Al-Jabr (2014). Finally, the dependent variable-attitude was measured with four items adapted from Akturan and Tezcan (2012). All items in part two were measured with Likert-scale items ranging from strongly disagree with the value of 1 and strongly agree with the value of 5. Moreover, all the items were translated into the Turkish language with authorized translators because the original source of measures is in the English language. For reassurance, the measures were back-translated before the distribution of the items. Finally, the copy is checked by three bilinguals in which all of them have a business studies background.

\section{Reliability and Validity}

Reliability is the degree to which the measure of a construct is consistent or dependable (Bhattacherjee, 2012). As an important element in the research process, reliability enables the consistency and dependability of the study. For measuring reliability, the popular measure of internal consistency is an alpha coefficient of reliability or commonly Cronbach's alpha (Cohen et al., 2007). In multi-item measures, it is compulsory to check inter-item correlations. The reliability of this study is depicted in table 2 .

Table 2 indicates that all the constructs have good reliability because all dimensions have the reliability of greater than .70 . Based on the suggestion proposed by Guielford (1965) cited by Taleghani et al., (2011), the higher the Cronbach's alpha value, the higher the internal consistency is. If a value was higher than 0.70 , then it showed that the reliability of measurement was high. Table 2 shows that the value of the Cronbach's alpha ranges from 0.760 to 0.875 . This indicates a good acceptable internal consistency of the items in the scale for this study.

Table 2: Questionnaire Items

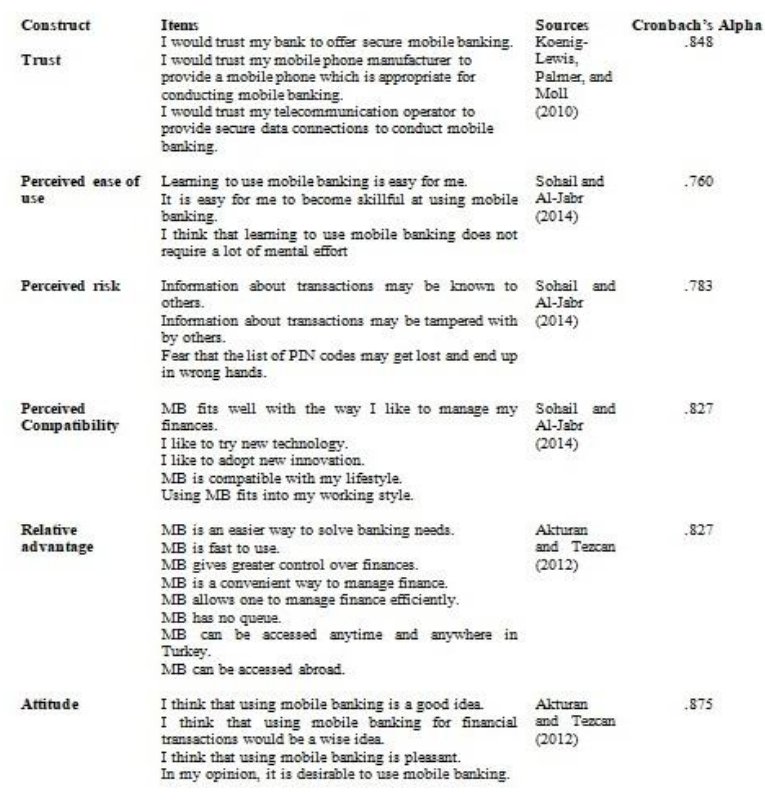




\section{Data Analysis and Interpretation}

Introduction

This chapter outlines the analysis of data and presents it. The results presented in this chapter are data collected through survey response from users and nonusers of mobile banking. Regarding the response rate, all 256 responses were fully filled, returned and found valid for further analysis. This is because the data were collected through online by making all questions compulsory for respondents. Therefore, there are no invalid and missing responses.

Demographic Profile of the Respondents

Table 3 depicts respondents profile including their gender, age, level of education, number and percentage of users and non-users of mobile banking, and purpose for the use of mobile banking.

Table 3: Demographic profile of the Respondents

\begin{tabular}{|c|c|c|c|c|c|c|}
\hline \multirow[b]{2}{*}{ Items } & \multicolumn{3}{|c|}{ Users } & \multicolumn{3}{|c|}{ Non-user } \\
\hline & & $\mathbf{N}$ & Percent & $\mathrm{N}$ & percent & Total \\
\hline $\begin{array}{l}\text { Gender } \\
22=11.181\end{array}$ & Male & 134 & 52.34 & 52 & & 186 \\
\hline $\begin{array}{l}\text { Phi }=.293 \\
\text { Cramer's } \\
\text { V }=.293\end{array}$ & Female & 46 & 18 & 24 & 9.4 & 70 \\
\hline Age & $<20$ & 12 & 4.7 & 26 & 10.16 & 38 \\
\hline$\gamma 2=33.182$ & $20-30$ & 178 & 69.53 & 22 & 8.6 & 200 \\
\hline Phi $=.505$ & $31-40$ & 16 & 6.25 & 0 & 0 & 16 \\
\hline Cramer's & $41-50$ & 2 & 8 & 0 & 0 & 2 \\
\hline $\mathrm{V}=.505$ & Above 50 & & & & & \\
\hline $\begin{array}{l}\text { Level of } \\
\text { education }\end{array}$ & $\begin{array}{l}\text { Primary and } \\
\text { Secondary school }\end{array}$ & 0 & 0 & 0 & 0 & 0 \\
\hline$\gamma 2=30.301$ & Highschool & 5 & 2 & 8 & 3.1 & 13 \\
\hline Phi $=.483$ & Associate degree & 31 & 12.1 & 17 & 6.64 & 48 \\
\hline Cramer's & Bachelor's degree & 100 & 39 & 43 & 16.8 & 139 \\
\hline $\mathrm{V}=.483$ & Master and above & 42 & 16.41 & 10 & 3.9 & 52 \\
\hline $\begin{array}{l}\text { Do you use } \\
\text { mobile } \\
\text { banking? }\end{array}$ & & 180 & 70.3 & 76 & 29.7 & 256 \\
\hline If your & To deposit money & 14 & 7.8 & & & \\
\hline $\begin{array}{l}\text { answer for } \\
\text { the above }\end{array}$ & To withdraw money & 21 & 11.67 & & & \\
\hline question is & For online shopping & 19 & 10.56 & & & \\
\hline $\begin{array}{l}\text { what } \\
\text { purpose(s) }\end{array}$ & Checking balance & 50 & 27.7 & & & \\
\hline $\begin{array}{l}\text { you use } \\
\text { mobile } \\
\text { banking? }\end{array}$ & All of the above & 76 & 42.2 & & & \\
\hline
\end{tabular}

As shown in Table 3, 72.65 percent of the respondents were males whereas 27.34 percent of the respondents were females. Regarding age, the majority of the respondents (78.13\%) are between the ages of 20-30. This is because the sample was drawn on public university students. As shown in Table 3, the majority of respondents are educated.

Table 3 depicts that, majority of the respondents $(70.3 \%)$ are users of mobile banking at least for one purpose. Among the users of mobile banking, the respondents use mobile banking for the purposes of depositing money $(7.8 \%)$, to withdraw money $(11.67 \%)$, for online shopping $(10.56 \%)$, checking balance $(27.7 \%)$, and $57(42.2 \%)$ of the respondents use mobile banking for all reasons stated above. Moreover, there is a significant number of respondents who use mobile banking in addition to the reasons stated above like transferring money and for forex services.
In addition, Chi-square tests (both Phi and Cramer's V) were conducted. The results indicated that, there is a difference across gender on attitudes towards the adoption of mobile banking. Similarly, there is a difference across the level of education and users' and non-users' attitudes towards the adoption of mobile banking. McHugh (2013) stated the assumption of chisquare as "The value of the cell expected should be 5 or more in at least $80 \%$ of the cells, and no cell should have an expected of less than one". The dimensions of gender and level of education satisfied this assumption. However, age violated the assumption of chi-square, because 4 cells $(50 \%)$ have expected count less than 5 .

Trust

Morgan and Hunt (1994) conceptualized that, trust exists when one party has confidence in an exchange partner's reliability and integrity. Shifera Bekele (2011), noted that, in practical business activities, the development of trust is considered to be a critical result of establishing a long-term successful relationship among all the parties involved. In the face of complicated service markets, customers tend to behave and make purchasing decision depending on their previous consuming experiences. Investing in a long-term relationship with customers helps to develop customer trusts and improve the effective quality of a relationship in order to obtain mutual interests. As shown in Table 4, the correlation coefficient between trust and attitude is 0.475 at a $P$ value of 0.01 . Therefore, there is a moderate relationship between trust and both users' and non-users' attitude towards the adoption of mobile banking.

Table 4: Correlations between Variables

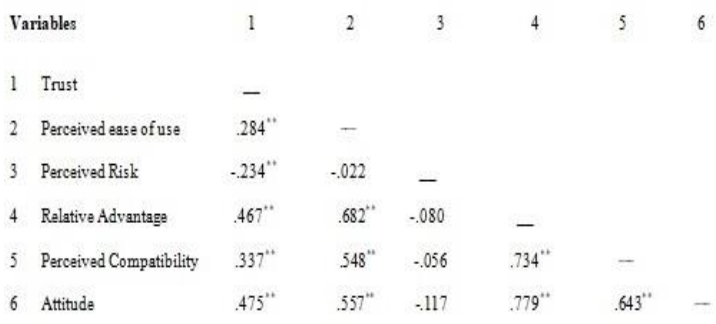

**. Correlation is significant at the 0.01 level

Perceived Ease of use

As shown in Table 4, the correlation coefficient between perceived ease of use and attitude is .557 significant at a $P$ value of 0.01 . This implies that, there is a moderate relationship between perceived ease of use and attitude towards the adoption of mobile banking both for users and non-users.

\section{Perceived Risk}

Unlike the other variables, perceived risk is found to have no relationship with user and non-user attitudes towards the adoption of mobile banking. The correlation coefficient between perceived risk and users' and non-users' attitude towards adoption of mobile 
banking as shown in Table 4 is -.117 with an inclination towards negative weak correlation, which is not significant at a $P$ value of .01 .

\section{Relative Advantage}

As shown in Table 4, the correlation coefficient between relative advantage and attitude is .779 significant at a $\mathrm{P}$ value of 0.01 . This implies that, there is a strong relationship between relative advantage and users' as well as non-users' attitude towards the adoption of mobile banking.

\section{Perceived Compatibility}

Table 4 indicates that, the correlation coefficient of .643 is significant at a $P$ value of 0.01 . This implies that, perceived compatibility is found to have moderately correlation with users' and non-users' attitude towards the adoption of mobile banking.

\section{Group Comparison with ANOVA}

Since one of the objectives of this study is to compare the user and non-user attitude towards the adoption of mobile banking, ANOVA is used for the analysis. The results shown in Table 5 indicates that trust, perceived ease of use, compatibility and relative advantage are found to have a significant difference between users and non-users of mobile banking. All of the findings are significant at the value of $(P<.01)$. However, perceived risk has no significant difference between users' and non-users' attitude towards the adoption of mobile banking. The descriptive and ANOVA results are displayed in Table 5 and Table 6 respectively.

Table 5: Descriptive Results

\begin{tabular}{|ll|r|r|r|}
\hline & & $\mathrm{N}$ & Mean & Std. Deviation \\
\hline Trust & Non-user & 76 & 9.0417 & 2.31214 \\
& User & 180 & 10.6321 & 2.50837 \\
& Total & 256 & 10.3385 & 2.54130 \\
\hline Perceived Ease of Use & Non-user & 76 & 10.9583 & 1.68056 \\
& User & 180 & 12.6981 & 1.74121 \\
& Total & 256 & 12.3769 & 1.85215 \\
\hline Perceived Risk & Non-user & 76 & 8.4583 & 3.03572 \\
& User & 180 & 8.5094 & 2.87268 \\
& Total & 256 & 8.5000 & 2.89145 \\
\hline Perceived Compatibility & Non-user & 76 & 17.6667 & 2.51373 \\
& User & 180 & 20.5943 & 2.93023 \\
& Total & 256 & 20.0538 & 3.06850 \\
\hline Relative Advantage & Non-user & 76 & 29.2083 & 4.71795 \\
& User & 180 & 32.2264 & 4.40840 \\
& Total & 256 & 31.6692 & 4.60096 \\
\hline
\end{tabular}

Table 5 above shows descriptive results about mean, standard deviation, standard error, lower bound and upper bound of the factor results influencing attitude towards the adoption of mobile banking for both users and non-users.

\section{Table 6: ANOVA}

\begin{tabular}{|ll|r|r|r|r|r|}
\hline & & \multicolumn{1}{|c|}{$\begin{array}{c}\text { Sum of } \\
\text { Squares }\end{array}$} & \multicolumn{1}{c|}{ df } & Mean Square & F & Sig. \\
\hline Trust & Between Groups & 49.498 & 1 & 49.498 & 8.085 & .005 \\
& Within Groups & 783.609 & 128 & 6.122 & & \\
& Total & 833.108 & 129 & & & \\
\hline Perceived Ease of Use Between Groups & 59.233 & 1 & 59.233 & 19.780 & .000 \\
& Within Groups & 383.298 & 128 & 2.995 & & \\
& Total & 442.531 & 129 & & & \\
\hline Perceived Risk & Between Groups & .051 & 1 & .051 & .006 & .938 \\
& Within Groups & 1078.449 & 128 & 8.425 & & \\
& Total & 1078.500 & 129 & & & \\
\hline Perceived & Between Groups & 167.733 & 1 & 167.733 & 20.508 & .000 \\
Compatibility & Within Groups & 1046.890 & 128 & 8.179 & & \\
& Total & 1214.623 & 129 & & & \\
\hline Relative Advantage & Between Groups & 178.253 & 1 & 178.253 & 8.939 & .003 \\
& Within Groups & 2552.524 & 128 & 19.942 & & \\
& Total & 2730.777 & 129 & & & \\
\hline
\end{tabular}

\section{Discussion}

The ever-increasing competition and proliferation of technology have brought new frontiers for challenges and opportunities for serving customers and keep them loyal (Baabdullah, et al., 2019). Mobile banking as an alternative form of service distribution channel is widely documented with the predictors which can influence its attitude towards adoption (Farah, Hasni, and Abbas, 2018; Baabdullah et al., 2019; Koenig-Lewis, Palmer, and Moll (2009). Extant literature indicates that there is a difference between users and nonusers' adoption of mobile banking across cultures (Sohail and Al-Jabr, 2014). This study's findings indicated that some of the influencing factors are found to have no, moderate and strong correlation with users and nonusers' attitude towards the adoption of mobile banking.

Trust is the partners' confidence in exchange for partners reliability and integrity (Morgan and Hunt, 1994). They also asserted that in rational contracting behavior, trust plays a vital role between exchange partners. The trust between the exchange partners leads to productivity and efficiency preceded by cooperative behavior (Morgan and Hunt, 1994). For the successful exchange to exist, partners must trust each other. This is more important for consumers who have little strength on quid pro quo when service providers fail to offer as promised. The absence of a direct in-person connection between consumers and service providers in mobile banking makes trust among one of the important influencing factors in the adoption of users and nonusers' attitudes towards mobile banking.

In this study, trust found to have, moderate relationship with an attitude of users and nonusers towards mobile banking. Koenig-Lewis, Palmer, and Moll (2009) found that trust can influence behavioral intention. Moreover, the ANOVA result indicated that there is a difference between users and nonusers with regard to trust in the attitude towards the adoption of mobile banking.

Perceived ease of usefulness (PEU) can be defined as the degree to which an innovation is easy to use (Lin, 2010). Davis (1989) defined PEU as achieving innovation with free of effort and perceiving that mobile banking is advantageous and make service easier (Akturan, 2012). PEU is found to be one of the important 
factors that can influence users and nonusers' attitude towards the adoption of mobile banking. The findings indicated that there is a moderate relationship between perceived ease of use and attitude. Moreover, there is a difference between users and nonusers' perceived ease of use on the attitudes towards the adoption of mobile banking.

Perceived risks are factors that make consumer contemplate about the nature and amount of risk for purchase decision (Bauer, 1960). The nature of risk differs from service to service and product to product. In this study, perceived risk has no significant relationship with users and nonusers' attitude towards the adoption of mobile banking. Similarly, there is no significant difference between users and nonusers' attitude towards the adoption of mobile banking regarding perceived risk.

Shareef et al. (2008) defined perceived functional benefit as "the degree to which consumers perceive the overall functional benefits, both absolute and relative-including cost, time, efficiency, and effectiveness of using mobile banking system-instead of using traditional physical office functions". It is the users' comparison for the services provided through mobile with other models of services.

Relative advantage elicits the consumers perceived comparison for a product in relation with others (Shareef et al., 2018). This involves factors like efficiency, cost, time, and effectiveness of a given product with others. The advent of technology is by the assumption that it can ease and reach users with minimum cost and effort. This study's finding indicated that relative advantage has a strong positive relationship between users and nonusers' attitude towards the adoption of mobile banking. This finding is similar to the existing literature's findings like Akturan and Tezcan (2012)

The existing beliefs, values, experiences, and habits of the consumers for new innovation is one of the influencing factors for attitudes towards the adoption of mobile banking (Chen and Tan, 2004; Sohail and AlJabr, 2014). The result indicates that there is a moderate relationship between compatibility and users and nonusers' adoption of mobile banking. In the Indian context, Chawla (2017) also found that lifestyle compatibility has a positive and significant effect on user intention. Moreover, there is a difference between users and nonusers on the attitude towards the adoption of mobile banking vis-à-vis compatibility.

\section{Conclusion, Limitations and Future Research Directions}

The factors influencing users and nonusers' attitude towards the adoption of mobile banking one of the contemporary research areas especially from perspectives of users in emerging markets and developing countries with the spread of technology. This study attempted to identify and indicate the factors influencing users and nonusers' adoption of mobile banking in Turkey. Moreover, the findings of this study identified and indicated how users and nonusers' attitude is influenced across gender and level of education.

The findings indicated the correlation between four of the influencing variables (viz. trust, perceived ease of use, compatibility, and relative advantage) and users and nonuser adoption of mobile banking. However, perceived risk found to have no relationship with both users and nonusers attitude towards the adoption of mobile banking.

Managerially, this study can provide insights about how users and nonusers attitude towards mobile banking can be influenced. This lets managers focus their innovation on factors like lifestyle compatibility that fits with different types of customers, and relative advantage alongside with trust and perceived ease of use. Moreover, the demographic differences also have its own implication on devising innovations that consider those differences.

This study had the following limitations. One limitation is the data for this study were collected from students which would have more interest to try new innovation and have knowledge about new technology. Concurrently, the first limitation is associated with the second limitation which is pooling of age groups to narrow domain. Moreover, the study employed a convenience sampling technique and data were collected from only Ankara Turkey. Thus, future research should consider conducting studies in entire Turkey and other settings, especially cross-cultural studies. To recall, most of the respondents were users of mobile banking. This suggests that mobile banking has become an established mode of service delivery. Therefore, future researchers should consider studies on the relationships between service quality, users satisfaction, and loyalty to the brand.

\section{References}

Baabdullah, A.M., Alalwan, A.A., Rana, N.P., Kizgin, H. \& Patil, P. (2019). Consumer use of mobile banking (M-Banking) in Saudi Arabia: Towards an integrated model. International Journal of Information Management, 44, 3852.

Bhattacherjee, A. (2012). Social Science Research: Principles, Methods, and Practices, (2nd edition). The Global Text Project.

Boateng, H., Adam, D.R., Okoe, F.A., and Dorson, T.A. (2016). Assessing the determinants of internet banking adoption intentions: A social cognitive theory perspective. Computers in Human Behavior 65, 468-478. 
Calhoun, K.J., Teng, J.T.C., and Cheon, M.J., (2002). Impact of national culture on information technology usage behavior: an exploratory study of decision making in Korea and the USA. Behavior \& Information Technology, 21 (4), 293-302.

Chakiso, C.B. (2015). The effect of relationship marketing on customers loyalty: Evidence from Zemen Bank. Emerging markets Journal, Volume 5 No 2, DOI 10.5195/emaj.2015.84.

Chawla, D. and Joshi, H. (2017). High Versus Low Consumer Attitude and Intention Towards Adoption of Mobile Banking in India: An Empirical Study. Vision, 21 (4), 1-15.

Cláudio Hoffmann Sampaio, Wagner Junior Ladeira, Fernando De Oliveira Santini, "Apps for mobile banking and customer satisfaction: a cross-cultural study", International Journal of Bank Marketing, https://doi.org/10.1108/IJBM09-2015-0146

Cohen, L. Manion, L. and Morrison, K., (2007). Research Methods in Education. (6th edition), Routledge Taylor \& Francis publications Group, London and New York.

Davis, F.D., Bagozzi, R.P., and Warshaw, P.R., (1989). User acceptance of computer technology: a comparison of two. Management Science, 35 (8), 982-1002.

Etzo, S. and Collender, G. (2010). Briefing the Mobile Phone 'Revolution' In Africa: Rhetoric or Reality? African Affairs, 109/437, 659-668.

Farah, M.F., Hasni, M.J.S., and Abbas, A.K. (2018). Mobile-banking adoption: empirical evidence from the banking sector in Pakistan. International Journal of Bank Marketing, https://doi.org/10.1108/IJBM-10-2017-0215.

Featherman, M.S., \& Pavlou, P.A. (2003). Predicting eservices adoption: a perceived risk facets perspective. International Journal of HumanComputer Studies, 59, 451-474.

Forsythe, S.M. \& Shi, B. (2003). Consumer patronage and risk perceptions in Internet shopping. Journal of Business Research, 56 (2003) 867875.

Gao, L., \& Waechter, K. A. (2015). Examining the role of initial trust in user adoption of mobile payment services: An empirical investigation. Information System Frontiers, 19, 525-548.
Jacoby, J. and Kaplan, L.B. (1972). The components of perceived risk, in Venkatesan, M. (Ed.), Third Annual Conference of the Association for Consumer Research, Association for Consumer Research, College Park, MD, 382-93.

Kaplan, L.B., Jacoby, J. and Szybillo, G. (1974). Components of perceived risk in product purchase: a cross-validation. Journal of Applied Psychology, Vol. 59 No. 3, 287-91.

Khasawneh, M.H. (2015). An Empirical Examination of Consumer Adoption of Mobile Banking (MBanking) in Jordan. Journal of Internet Commerce, 14:341-362.

Kidane Assefa, (2012). Relationship Marketing in the Hotel Industry: The Nexus between Concepts and Practices (A case of Ghion Hotel, Addis Ababa Branch, Ethiopia). Unpublished MA Project. Addis Ababa University.

Kim, G., Shin, B., \& Lee, H.G. (2009). Understanding dynamics between initial trust and usage intentions of mobile banking. Info Systems Journal, 19, 283-311.

Koenig-Lewis, N., Palmer, A. and Moll, A. (2010). Predicting young consumers' take up of mobile banking services. International Journal of Bank Marketing 28(5), pp. 410-432.

Kolodinsky, J.M., Hogarth, J.M., Hilgert, M.A. (2004). The adoption of electronic banking technologies by US consumers. The International Journal of Bank Marketing, Vol. 22 No. 4, pp. 238-259.

Kothari, C.R. (2004). Research Methodology Methods and Techniques. (2nd edition). New Age International Publishers, India.

Kotler, P. and Keller, K.L. (2012). Marketing Management. 14th edition. Pearson Education Inc.

Laforet and Li (2005). Consumers' attitudes towards online and mobile banking in China. International Journal of Bank Marketing, Vol. 23 No. 5, pp. 362-380.

Laukkanen, T. (2017). Mobile banking. International Journal of Bank Marketing, Vol. 35 Issue: 7, pp.1042-1043, https://doi.org/10.1108/IJBM10-2017-0218.

Laukkanen, T., \& Pasanen, M. (2008). Mobile banking innovators and early adopters: How they differ from other online users? Journal of Financial Services Marketing, 13(2), 86-94. 
Lin, H.F. (2011). An empirical investigation of mobile banking adoption: The effect of innovation attributes and knowledge-based trust. International Journal of Information Management 31, 252-260.

Luo, X., Lin, H., Zhang, J. \& Shim, J.P. (2010). Examining multi-dimensional trust and multifaceted risk in initial acceptance of emerging technologies: An empirical study of mobile banking services. Decision Support Systems, $49,222-234$

Malaquias, R.F., and Hwang, Y. (2016). An empirical study on trust in mobile banking: A developing country perspective. Computers in human behavior. 54, 453-461.

Masrek, M. N., Nor'ayu, A. U., \& Irni, I. K. (2012). Trust in Mobile Banking Adoption in Malaysia: A Conceptual Framework. Journal of Mobile Technologies, Knowledge \& Society, 2012, 1-12.

McHugh, M.L., (2013). The Chi-square test of independence. Biochemia Medica; 23(2):1439.

Morgan, R. \& Hunt, S. (1994). The Commitment-Trust Theory of Relationship Marketing. Journal of Marketing. Vol. 58, p20-38.

Muge Arslan, F. and Altuna, O.K. (2010). The effect of brand extensions on product brand image. Journal of Product \& Brand Management. 19/3, 170-180. Emerald Group Publishing Limited.

Mullan, J., Bradley, L., \& Loane, S. (2017). Bank adoption of mobile banking: stakeholder perspective. International Journal of Bank Marketing, https://doi.org/10.1108/IJBM-092015-0145

Murray, K.B. (1991). A Test of Services Marketing Theory: Consumer Information Acquisition Activities. Journal of Marketing, Vol. 55, No. 1, pp. 10-25.

Neuman, W.L. (2014) Social Research Methods: Qualitative and Quantitative Approaches, Seventh Edition, Pearson Education Limited.

Riquelme, H.E., and Rios, R.E. (2010). The moderating effect of gender in the adoption of mobile banking. International Journal of Bank Marketing. Vol. 28 No. 5, pp. 328-341.

Rogers, E. (2003). Diffusion of innovations. 5th ed. New York: Free Press.
Roselius, T. (1971). Consumer rankings of risk reduction methods. Journal of Marketing, Vol. 35, No. 1, pp. 56-61.

Shareef, M.A., Baabdullah, A., Dutta, S., Kumar, V., and Dwivedi, Y.K. (2018). Consumer adoption of mobile banking services: An empirical examination of factors according to adoption stages. Journal of Retailing and Consumer Services, 43, 54-67.

Sharma, S.K. \& Sharma, M. (2019). Examining the role of trust and quality dimensions in the actual usage of mobile banking services: An empirical investigation. International Journal of Information Management 44, 65-75.

Singh, S., Srivastava, R.K. (2018). Predicting the intention to use mobile banking in India. International Journal of Bank Marketing, https://doi.org/10.1108/IJBM-12-2016-0186.

Sohail, M.S., and Al-Jabri, I.M. (2014). Attitudes towards mobile banking: are there any differences between users and non-users? Behaviour \& Information Technology, Vol. 33, No. 4, 335-344.

Szopiński, T.S. (2016). Factors affecting the adoption of online banking in Poland. Journal of Business Research.

Taleghani, M. Gilaninia, S., and Mousavian, S.J. (2011). The Role of Relationship Marketing in Customer Orientation Process in the Banking Industry with focus on Loyalty (Case Study: Banking Industry of Iran). International Journal of Business and Social Science Vol. 2 No. 19.

Tam, C. \& Oliveira, T. (2016). Understanding the impact of m-banking on individual performance: DeLone \& McLean and TTF perspective. Computers in Human Behavior, 61, 233-244.

Taylor, S., and Todd, P. A. (1995b). Understanding Information Technology Usage: A Test of Competing Models. Information Systems Research (6:2), pp.144-176.

Wan, W.N., and Chow, C.L. (2005). Customers' adoption of banking channels in Hong Kong. International Journal of Bank Marketing, Vol. 23 No. 3, pp. 255-272.

Williamson, O.E. (2007). Transaction Cost Economics: An Introduction. Economic discussion papers, 3.

Yiu, S.Y., Grant, K., and Edgar, D. (2007). Factors affecting the adoption of Internet Banking in Hong Kong-implications for the banking sector. International Journal of Information Management 27, 336-351. 